\title{
TRAINING PERCEPTION AND WORK ENGAGEMENT: THE MEDIATING ROLE OF ORGANISATIONAL-BASED SELF- ESTEEM AND SELF-EFFICACY
}

\section{Tran Huy, Phuong; Dinh, Thi Ngoc Quynh}

Phuong Tran Huy / National Economics University, Faculty of Human Resource Economics and Management. 207 Giai Phong Street, Hanoi, Vietnam. Email: phuongth@neu.edu.vn

Thi Ngoc Quynh Dinh / Foreign Trade University, Faculty of Japanese. 91 Chua Lang Street, Hanoi, Vietnam. Email: quynhdtnjp@ftu.edu.vn

\begin{abstract}
This article aims to investigate the impact of training perception on work engagement. In addition, self-efficacy and organisational based self-esteem are hypothesised as mediators of the above relationship. Data were collected from employees in Vietnam using a selfadministered questionnaire survey. Path analyses with Structural Equation Modelling (SEM) were used to verify the proposed relationships. The results show that both perceived training benefits and transfer of training significantly and positively influence work engagement. In addition, organisational based self-esteem partially mediates the impact of perceived training benefit on work engagement. Self-efficacy mediates a portion of the effects of the transfer of training on work engagement. The results add to the existing literature on the determinants of work engagement and on the consequences of the transfer of training. The findings also provide insight into the conditions for effective training in organisations.

Implications for Central European audience: Developing an engaged workforce is a vital task to all organisations. However, data showed that the work engagement level in Europe is low, especially in Central Europe. The results of the study provide insight into the determinants of employee engagement at work. In addition, like Vietnam, most countries in Central Europe have been in transition from former central-command systems to market economies. The application of contemporary Western human resource practices needs special consideration to ensure its effectiveness. The current study may supply some empirical implications for both academics and practitioners.
\end{abstract}

Keywords: work engagement; training benefit; transfer of training; organisational based selfesteem; self-efficacy

JEL classification: J28, M12, M53

\section{Introduction}

Employees' work engagement (WE) has been a much-attended research topic for the last ten years, and research interests in the topic seem to continue (Saks, 2019; Wollard \& Shuck, 2011). Work engagement is associated with employees' and organisational performance (Anitha, 2014; Dhir \& Shukla, 2019; Saks, 2006; Xanthopoulou et al., 2009). However, there 
are concerns about the diminishing WE worldwide. Towers Watson (2012) surveyed 32,000 employees in 30 countries and found that only about one-third of the workforce is engaged, while $17 \%$ are detached, and $26 \%$ are disengaged. Gallup's report (2017) showed that only one-sixth (15\%) of workers show engagement at work in 2017 worldwide. These figures showed that almost four out of five workers are not living up to their full potential or not wholeheartedly contribute to their organisations' success. More worrying, almost two out of five employees only do minimum to get by or are completely disengaged. Such numbers indicate the necessity to increase the level of engagement, thus generate higher organisational outcomes. In the ever-changing business environment, engaging employees has become an overwhelming challenge to managers in organisations (Dhir \& Shukla, 2019). As a result, voluminous research attention has been put forward to identifying the determinants of work engagement.

Saks (2006) developed a model of predictors and outcomes of WE, which highlighted the role of job characteristics, rewards and recognitions, perceived support, and fairness as predictors of employee engagement. Other literature has investigated numerous factors that influence WE, including personal psychological and perceptual state, job-related characteristics and organisational policies and practices (Anitha, 2014; Bailey et al., 2017; Dhir \& Shukla, 2019; Wollard \& Shuck, 2011). Salanova et al. (2005) concluded that organisational resources (training, autonomy and technology) positively influenced WE. Similarly, Demerouti et al. (2001) advocated that job resources (e.g., feedback on performance, supervisor support, and job control) were determinants of WE. Nevertheless, Wollard and Shuck (2011) posited that although many antecedents of WE have been identified, not many of them have been empirically tested and called for more research on the topic. The current research seeks to identify the impact of training on WE among employees in Vietnamese organisations via the intermediary of organisation-based self-esteem (OBSE) and self-efficacy. In achieving this aim, the current study makes the following contributions to the literature.

First, unlike previous research, which considered organisational interventions and personal psychological states as horizontal antecedents of WE, in this research, the individual psychological state was verified as a mediator of the training-engagement linkage. More specially, in this research, the OBSE and self-efficacy were expected to act as intermediary channels in the relationship between training perception and WE. Because there were pieces of evidence that the influence of training on employees' performance and attitudes is likely to be indirect and tend to be delivered via intermediary variables such as motivational processes that direct energies towards goal attainment (Dysvik \& Kuvaas, 2008), this analysis could provide more information to legitimate the issue. Moreover, Truss et al. (2013) signified a clear need for further research that expands extant knowledge about the psychological processes underpinning work engagement.

Second, previous research concluded that although employee and organisational development are strong predictors of employee engagement, few empirical studies examined the role of such variables on WE (Wollard \& Shuck, 2011). This research responds to this call by testing the association between training, an important employee and organisational development practices, and WE. Although there were studies that explored the relationship between training and individual outcomes such as engagement, these studies investigate training either as a component of HRD systems and organisational resources or as a part of a high-performance work system (Ling Suan \& Nasurdin, 2014; Memon et al., 2016; Salanova 
et al., 2005). Consequently, the relationship between training and WE may be affected by other HRD components. Arrowsmith and Parker (2013) asserted that the influences of particular HRM practices on work engagement are still under-researched. This research addresses the influence of training, as a standalone organisational practice, on WE.

Third, the impact of training on employee attitude and behaviour varies with the trainee's perception of the purpose and relevance of training. According to Nishii et al. (2008), employee perception about training may greatly vary due to the differences in experience and perception about its purposes. The success of training activities will strongly depend upon not just employee's individual personalities but also their perception about training's benefits or outcomes (Burke \& Hutchins, 2007). There were pieces of evidence that such perception has considerable impacts on productivity, performance and level of engagement (Kuvaas \& Dysvik, 2009; Salanova et al., 2005). In this research, the influence of training perception on employee engagement was explored, rather than training itself. Previous research also investigated the linkage between training perception and engagement (Fletcher, 2016; Memon et al., 2016). However, in these studies, the authors used the concept of training satisfaction, defined by Schmidt (2007) as "the extent to which people like or dislike the set of planned activities organised to develop the knowledge, skills, and attitudes required to effectively perform a given task or job" to measure training perception. The current study, however, examines training perception as the trainees' belief about the benefits and outcomes of training. Specifically, in this research, we focus on the perception of training benefits which has been investigated by Bartlett (2001) as a predictor of organisational commitment.

Fourth, although the transfer of training has been a very important issue to be addressed, literature mainly focuses on the predictive factors of training transfer (Burke \& Hutchins, 2007). Zumrah et al. (2013) identifies the scarcity of practical proof on the consequences of training transfer and advocates a need to understand the outcomes of training transfer in the workplace. This study responds to the call by investigating work engagement as a consequence of the transfer of training.

The rest of the article will be constructed as follows: in the next section, we review the literature on employee engagement, training perception, OBSE and self-efficacy. We have also explained the mediating role of OBSE and self-efficacy on the links between training perception and WE. Then, the study explains the research method and results. Finally, we discuss the implications, limitations and direction for subsequent studies.

\section{Theoretical background}

\subsection{Work engagement}

For nearly two decades of researching and developing, the definition of WE is still raising controversy among researchers and practitioners (Knight et al., 2017). In other words, there still have no universally accepted definition for this term, but it varied depends on how researchers and people look at it. Kahn (1990) conceptualised engagement as "the harnessing of organisation members' selves to their work roles; in engagement, people employ and express themselves physically, cognitively, and emotionally during role performances". He argued that people with engagement are enabled to concomitantly expose their preferred selves and entirely fulfil their role duties. More recently, Schaufeli et al. (2002) 
defined WE "as a positive, fulfilling, work-related state of mind that is characterised by vigour, dedication, and absorption" (p. 74). In which vigour involves exerting continuous effort and energy in work, dedication measures the level of involvement in the work with enthusiasm and sense of responsibility, and absorption means concentration and engrossment in one's work (Schaufeli et al., 2002). The definition put forwards by Schaufeli et al. (2002) has been adopted by a large number of research studies (Bailey et al., 2017).

\subsection{Training and training perception}

Training has been conceptualised in many ways by various researchers. Landy (1985) defined job training as "a set of planned activities on the part of an organisation to increase the job knowledge and skills or to modify the attitudes and social behaviour of its members in ways consistent with the goals of the organisation and the requirements of the job". According to Armstrong (2000), "training is the systematic development of the knowledge, skills and attitudes required by an individual to perform adequately a given task or job". More recently, Aguinis and Kraiger (2009) refer training to "the systematic approach to affecting individuals' knowledge, skills, and attitudes in order to improve individual, team, and organisational effectiveness". Training is primarily linked to the improvement and upgradation of the competencies of the workers and emphasises workers behaviour in order to enhance the present and future state of job performance (Costen \& Salazar, 2011). The success of training activities will strongly depend upon not just employee's individual personalities but also their perception about its benefits or outcomes (Burke \& Hutchins, 2007). Previous research demonstrated that such perception has considerable impacts on productivity, performance and level of engagement (Kuvaas \& Dysvik, 2009; Salanova et al., 2005; Truitt, 2011). Santos and Stuart (2003), in a qualitative study on training effectiveness, found that trainees' cognitive evaluation of the training environment, the expected outcomes and the transfer of knowledge gained from training into daily work strongly predict training effectiveness. Regarding the perception of training outcomes, they suggested a clear distinction of intrinsic and extrinsic outcomes from their interview. Thus, the perception of training outcomes can be categorised into intrinsic and extrinsic ones. Intrinsic outcomes refer to ability, motivation at work and personal growth, while extrinsic outcomes focus on higher pay, better promotion, and career progression.

Transfer of training is referred to the application of skills and knowledge acquired in training into the actual work (Baldwin \& Ford, 1988). Santos and Stuart (2003) suggested that, for some employees, although they can experience and feel the benefits of training, they find it uneasy about utilising what they learned in their work. The author pointed out that both pretraining and post-training activities can boost transferability. Careful need assessment, participative discussion about training content and methods, and clear performance enhancement targets were identified as helpful in the application of learning into real work. Post-training activities such as the provision of contexts to apply learned skills and supplying adequate resources for such application were considered critical for successful training transfer.

\subsection{Organisation-based self-esteem}

OBSE is conceptualised as the perception of employees regarding the extent to which their wants and needs can be fulfilled by working in an organisation (Pierce et al., 1989). Individuals on the upper end of the OBSE scale tend to have positive views of themselves as 
competent, significant and influential members of the organisation. OBSE was found to positively influence individual attitudes and behaviours such as job satisfaction and organisational commitment (Haar \& Brougham, 2016), turnover intention (Ahmad \& Begum, 2020), organisational citizenship behaviours (Kim \& Beehr, 2018), work-life outcome (Gordon \& Hood, 2020), and knowledge sharing behaviour (Tran Huy, 2019).

\subsection{Self-efficacy}

Self-efficacy can be defined as "'people's judgments of their capabilities to organise and execute the courses of action required to attain designated types of performances" (Bandura, 1986). Self-efficacy has been found to exert critical and vital impacts on positive behavioural and attitudinal outcomes. Research showed that workers with a high level of self-efficacy view difficulties as opportunities instead of threats (Manojlovich, 2005). Self-efficacy was positively related to the job and personal resources, which, in turn, result in engagement (Salanova, Llorens et al., 2011). The highly self-efficacious individual tends to hold a high effort-performance expectancy, which increases the individual's persistence of effort when pursuing goals (Carter et al., 2018). Besides, previous research showed that self-efficacy positively predicts employees' personal behaviour in various industrial and organisational settings (Haddad \& Taleb, 2016; Kaakeh et al., 2020; Stajkovic \& Luthan, 1998).

\section{Hypotheses development}

\subsection{Training perception and work engagement}

Literature on employee training suggested that training affects employees' attitudes such as job satisfaction, turnover intentions, organisational commitment and work motivation (Sahinidis \& Bouris, 2008; Schmidt, 2007; Skarlicki \& Latham, 1997) and behaviours such as in-role performance and organisational citizenship behaviour (Frayne \& Geringer, 2000; Guan \& Frenkel, 2019). Bakker et al. (2014), using the Job Demand-Resource (JD-R) approach, emphasised that training increases job resources by providing the employees with opportunities to exchange information and feedback. Training also enhances personal resources by fostering employees' skills and competencies. By these means, training fosters work engagement. Salanova et al. (2005) found that organisational resources, including training factors, had a strong impact on employee engagement. In another research, Luthans et al. (2010) suggested that training activities positively enhance both job performance and psychological capital, which consists of sub-dimensions closely related to engagement behaviour. More recently, Sendawula et al. (2018) concluded that training positively enhanced worker's job-related outcomes via the intermediary impact of work engagement.

The association between training and employee engagement can alternatively be explored through the lens of social exchange theory (SET) and the psychological contract framework. Social exchange theory (Blau, 1964) posited that individuals enter into a relationship with the purpose of maximising the benefits they gain from the relationship. Psychological contract literature proposed that the employee forms an implicit agreement with the employer based on mutual expectations (Rousseau, 1995). Psychological contracts operate based on reciprocity norms and have been verified to be a solid predictor of organisational behaviours (Bal et al., 2008; Zhao et al., 2007). Psychological contract literature highlighted the vital role of training in the employee-side perception of the psychological contract. Coyle-Shapiro and Kessler (2000) found that training is the third dimension of psychological contract together 
with the conventional relational-transactional continuum. Training can be viewed as a management obligation towards the employees, and according to the norm of reciprocity, in return for the fulfilment of this obligation, the employees will feel obligated to engage with their work. Because psychological contracts are internal cognitions held individualistically by the employee (Morrison \& Robinson, 1997), perception of the fulfilment of the obligations is more important than what has actually been done by the management.

Training perception was considered as one of the most vital individual perceptions which influence attitudes and behaviours towards training (Guest, 2002). There was a notation that the more positively employees perceive training activities in their workplace, the more greatly they achieve the level of motivating effect for taking training (Ahmad \& Bakar, 2003). Ahmad and Bakar (2003) reported a positive relationship between perceived training benefits and commitment and willingness to participate in subsequent training activities. Santos and Stuart (2003) indicated that employees who perceived non-monetary benefits of training such as career progress and personal growth were more committed to personal development activities such as continuous improvement (rigour), requesting feedback on performance (dedication) or career exploration (absorption). Bartlett (2001) concluded that in addition to perceived training accessibility, training support, and learning motivation, perceived benefits of training was positively associated with organisational commitment. He also suggested that individuals who acknowledge the benefits of training are likely to be more committed to their work. Because work engagement and organisational commitment are distinct but related constructs (Hallberg \& Schaufeli, 2006), it is hypothesised that:

\section{H1: Perception of the benefit of training is positively associated with employee engagement.}

Although training has a number of benefits, the transferability of what is gained from training to actual jobs remains a big concern for both managers and researchers (Santos \& Stuart, 2003). Santos and Stuart (2003) identified two reasons for the non-transferability of learning on the jobs in their interviews with managers, namely employees' hesitance to change and trainers' lack of understanding about the workplace. Furthermore, they found that both pretraining activities such as need analysis, participation in the content decision, and posttraining interventions like providing opportunities to use new skills and allocating the necessary resources were identified by most of the respondents as very important for effective training transfer. Employee engagement can be understood as the devotions of physical, cognitive and emotional resources into work (Kahn, 1990; Rich et al., 2010). Perception of training can exert influences on vigour, dedication and absorption, which were identified by Schaufeli et al. (2002) as the components of engagement. Vigour refers to the willingness to exert effort in work even in the case of hardship. Thus, the perception of training transferability may reduce the level of difficulty and make the work more interesting and affordable. If trainees perceive that they can transfer what they have acquired through training into their work, they may find the work more fulfilling and rewarding, which improve psychological identification with one's work, i.e. dedication. People absorbed in work are entirely concentrated on the job and may perceive that time flies and find it hard to leave the work. If learning can be applied successfully in work, the employees are likely to try different ways of doing the job, thus increase the level of absorption. Therefore, the following hypothesis is proposed: 


\subsection{Mediating impact of OBSE and self-efficacy}

Pierce et al. (1989) advocated that self-efficacy and OBSE are different constructs, in which OBSE reflects an employee's self-perceived competency within an organisation while selfefficacy involves the perception of competence that can be transformed into action that may result in high performance (p.625). That is, self-efficacy is more action-and result-oriented than OBSE.

Literature suggested a number of antecedents of OBSE ranging from traits, organisational context and structure to interpersonal relationships (Pierce \& Gardner, 2004). Pierce et al. (1989), using two school personnel samples, found a positive relationship between perceived managerial respect to the employee and OBSE. Chattopahyay and George (2001) indicated that trust in management was positively linked with OBSE. Because training can be viewed as management obligations towards the employees and a type of organisational resource (Salanova et al., 2005), employees who participate in training may have the feeling of being valued by the organisation, leading to a higher level of OBSE. Outdoor management education (OME) programs, which provide the participants with outdoor experiences that can be transferred back to the workplace, have been found to positively predict OBSE. McEvoy et al. (1997) found that participants in such programs reported higher levels of OBSE than those who did not experience the training program. Santos and Stuart (2003), in their study of employee perception toward training, indicated that respondents who received training within the past three months experienced higher job satisfaction, perceived better promotion prospects, and felt more valued by the company. It can be argued that, although the training programs are not necessarily directed towards actual tasks, participants who perceive the benefits of the training programs will experience the feeling of being valued by the organisation and of satisfying their needs. Therefore, perception training benefits will be positively related to OBSE.

OBSE has been reported to influence individual's workplace outcomes such as intrinsic motivation (Hui \& Lee, 2000), job satisfaction (Bowling et al., 2010; Gardner \& Pierce, 2016), organisational commitment (Haar \& Brougham, 2016; Van Dyne \& Pierce, 2004), organisational citizenship behaviour (Bowling et al., 2010; Kim \& Beehr, 2018) and job performance (Hahn \& Mathews, 2018; Van Dyne \& Pierce, 2004). Xanthopoulou et al. (2007) found that OBSE, representing a personal resource, was positively predicted work engagement. Pierce and Gardner (2004) advocated that OBSE acts as a mediating channel in the causal link between positive work characteristics (such as influence, fairness, support) and employee attitudes (such as job satisfaction, commitment) and performance (in-role and extra-role job behaviours). Therefore, it is hypothesised that:

\section{H3: OBSE mediates the effects of employees' training perception on work engagement.}

Self-efficacy is related to an individual's judgment of their ability to choose and implement a series of actions to achieve the designated goals (Niu, 2010). Employees higher in selfefficacy are more likely to feel motivated to persevere in achieving their goals, even in case of hardship (Bandura, 1997). Bandura (1997) proposed that self-efficacy is influenced by four important information sources: past performance, vicarious experience, verbal persuasion, and emotional cues. 
Past performance is the most important source of information for developing self-efficacy as it is related to the person's own experience. While success is thought to improve selfconfidence, failures may also improve an individual's ability to cope with other situations (Alshahrani \& Rasmussen Pennington, 2018). Training literature suggests that if the employees perceive transferability of training into work, they are more participative and active in subsequent training sessions (Sahinidis \& Bouris, 2008; Santos \& Stuart, 2003; Truitt, 2011). During training, employees do their tasks under the guidance and supervision of the trainers. Hence, they could have a chance to perform without considerable mistakes or have a chance to fix the wrong things immediately. Furthermore, by proactively participating in training and development sessions, the employees build up confidence in the area of the job through their own experience and enhance their self-confidence.

Vicarious experience refers to learning and drawing experience from observing others perform their work. Other persons can serve as an example (role model) and supply information about the degree of difficulty of a specific kind of behaviour. Observing others can enhance individual confidence about his or her abilities to imitate in similar situations. In a training session, active participants will not only learn from the trainers but also watch other people or teams performing relevant tasks. Thus, training can be a source of vicarious experience.

Verbal persuasion is the most popularly used source of self-efficacy due to its availability (Bandura, 1997). Praises, suggestions, instructions, and advices from trainers and other participants can make the employees feel confident that they can thrive even in a difficult task. Such interventions can be supplied in various training settings, and, if the employees are committed to learning, they will benefit from these.

Finally, the emotional cue is a source of information that influence perceived self-efficacy in dealing with stressful scenarios (Bandura, 1997). Because highly emotional behaviours may harm performance, employees are expected to be more successful if they are not stressed or become aggressive in difficult situations. Tai (2006) suggested that training opportunities may serve as important means to reduce uncertainty and enhance well-being at work because the participants have the chance to modify themselves in order to cope with the changes in the environment. Thus, training can be a source of the emotional cue. Because self-efficacy involves the application of self-perceived competence to the actual work (Pierce et al., 1989), it can be expected that the perception of training transferability enhances selfefficacy.

The impact of self-efficacy on work engagement has been tested in many previous studies (Carter et al., 2018; Mache et al., 2014). Lorente et al. (2014) found that self-efficacy positively related to the job and personal resources, which, in turn, result in engagement. Salanova et al. (2011) also reported that self-efficacy, as one of the personal resources, influences work engagement. Moreover, the mediating impact of self-efficacy on the relationship between training and individual outcomes has also been tested. Bakker et al. (2012) found that self-efficacy plays a mediating role in the relationship between active learning and job performance. Similarly, Schaufeli and Salanova (2008) viewed training as a type of organisational resource which influences self-efficacy, with the latter acts as a mediator to influence engagement and performance. Therefore, it is hypothesised that: 
H4: Employee's self-efficacy mediates the relationship between perception of training transferability and employee engagement.

\section{Research Method}

\subsection{Data collection}

A quantitative research design was adopted for the current study, with the use of a survey questionnaire to collect data. Data were collected from employees working in various enterprises in Hanoi and Hochiminh City, the two biggest cities in Vietnam. More than 55\% of business enterprises operating in Vietnam are located in Hanoi and Hochiminh City. Invitations to participate in the study were sent to 200 firms, randomly selected from the list of firms operating in the two cities. Eight enterprises in Hanoi and eleven in Hochiminh City decided to join in the research. Five of the firms are manufacturing companies; the remaining are service, software, and retail businesses. Four out of the 19 firms are small companies with less than 20 employees, 13 have between 20 and 200 employees, and two with more than 200 employees. Two firms are foreign-invested companies, and three are joint-ventures, ten are joint-stock companies, and four are private firms. The youngest firm was established in 2015, while the oldest firm was founded in 1999, with average firm age of 12 years.

Questionnaires were emailed to the participants at the participating firms. A total of 364 responses were collected; 168 from Hanoi and 196 from Hochiminh City. Female employees accounted for $36.5 \%$ (133), and male employees covered 63.5\% (231) of the total participants. Individual participants work in different departments, including sales and marketing, accounting and finance, production, human resource and engineering. About a quarter of the respondents (22\%) are in supervising positions. All of the respondents reported previous workplace training experience. The respondent's age averaged at 43, and an average respondent has a 13-year tenure at his or her organisation.

\subsection{Measure}

This study adopts a 5-point Likert score ranging from 1: "strongly disagree" to 5: "strongly agree" to measure the research variables.

- $\quad$ Perceived training benefit (BEN): The seven-item scale, adapted from Santos and Stuart (2003), was used to measure this variable. While the developers used this scale with a 3-point Likert choice: agree, neutral and disagree, this study uses the above mentioned 5-point Liker scale. Sample items include: "Training leads to higher pay" and "Training helps me to grow as a person". The reliability of this scale is 0.869 .

- $\quad$ Transfer of Training (TRANS): this variable was measured by the 3- item scale developed by Tesluk et al. (1995). An example is "I have been incorporating learned skills into daily work activities". This scale was validated in a few prior studies (Bhatti et al., 2013; Chauhan et al., 2017). In this research, the scale has a reliability score of 0.838

- $\quad$ Organisation-based self-esteem (OBSE): OBSE was measured using the scale developed by Pierce et al. (1989). Respondents were required to state their agreement with ten items; responses ranged from (1) strongly disagree to (5) strongly agree. Sample items of this Likert-type scale include "I am trusted around 
here" and "I am efficient around here". Cronbach's alpha is 0.830 in the current study.

- $\quad$ Self-efficacy (SE): This variable was measured with a 6-item short-form Generalised Self-Efficacy scale (GSE-6) developed by Romppel et al. (2013). The authors suggested that this scale is "a reliable and valid instrument that is useful for the economic assessment of general self-efficacy in large multivariate studies". The scale was also validated by Brunger and Spyra (2018), who concludes that "there were only minor differences when using the GSE-6 compared to the original version" developed by Schwarzer and Jerusalem (1995). Sample items include "It is easy for me to stick to my aims and accomplish my goals." or "I can usually handle whatever comes my way". A reliability score of 0.815 was obtained for this scale in the current study.

- Work engagement (WE): This study adopts the Ultra-Short Measure of Work Engagement UWES-3 (Schaufeli et al., 2019) to measure work engagement. The ultra-short scale has been validated across five countries. The scale is regarded by the authors as a reliable and valid indicator of work engagement, just as well as the longer 9-item version UWES-9 (Schaufeli et al., 2006). Respondents were asked to provide responses ranging from (1) strongly disagree to (5) strongly agree to their experience at work. Three statements referred to feelings of vigour: "At work, I am bursting with energy", dedication: "I am enthusiastic about my job", and absorption: "I am immersed in my work". Overall consistency for the engagement scale was 0.811 .

Figure 1 | Theoretical model

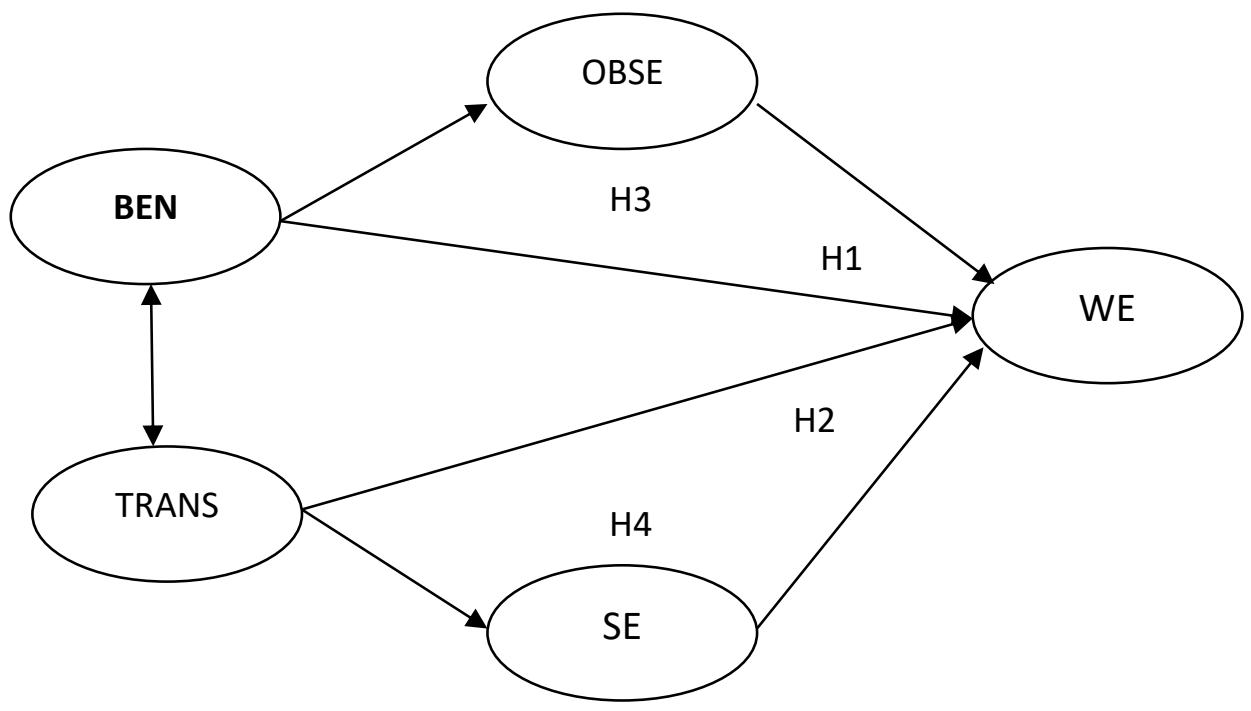

Source: authors 


\section{Results}

Table 1 | Mean, standard deviation, and correlations

\begin{tabular}{|c|c|c|c|c|c|c|c|c|c|c|}
\hline & Mean & S.D & $\alpha$ & 1 & 2 & 3 & 4 & 5 & 6 & 7 \\
\hline Gender & 0.64 & 0.43 & - & & & & & & & \\
\hline Age & 42.8 & 3.59 & - & $-0.219^{*}$ & & & & & & \\
\hline Tenure & 12.6 & 4.86 & - & -0.087 & 0.660 & & & & & \\
\hline $\begin{array}{l}\text { Work } \\
\text { Engagement }\end{array}$ & 3.77 & 0.56 & 0.811 & -0.061 & $0.140^{*}$ & 0.076 & & & & \\
\hline Training Benefit & 3.73 & 0.36 & 0.869 & -0.023 & -0.066 & 0.075 & $0.456^{*}$ & & & \\
\hline $\begin{array}{l}\text { Training } \\
\text { Transfer }\end{array}$ & 3.68 & 0.41 & 0.838 & 0.061 & 0.023 & 0.021 & $0.427^{*}$ & $0.414^{*}$ & & \\
\hline $\begin{array}{l}\text { Organizational- } \\
\text { based self- } \\
\text { esteem }\end{array}$ & 3.66 & 0.49 & 0.830 & -0.018 & 0.058 & 0.020 & $0.327^{*}$ & $0.232^{*}$ & $0.209^{*}$ & \\
\hline Self-Efficacy & 3.11 & 0.59 & 0.815 & 0.013 & 0.027 & 0.049 & $0.297^{*}$ & $0.250^{*}$ & $0.189 *$ & $0.246^{*}$ \\
\hline
\end{tabular}

\subsection{Reliability and validity}

Before testing the proposed hypotheses, the reliability and validity of the variables in the model were assessed. First, item loading for each item in any construct was validated to ensure that it is higher than 0.70 , as suggested by Chin (1998). Next, the composite reliability $(\mathrm{CR})$ score for all constructs were calculated. Figure in Table 1 showed satisfactory values of $\mathrm{CR}$ value for all variables $(\mathrm{CR}>0.7)$.

Table 2 | Reliability and validity of and correlations among research variables

\begin{tabular}{lcccccccc}
\hline & CR & AVE & MSV & WE & BEN & TRANS & OBSE & SE \\
\hline WE & 0.809 & 0.542 & 0.353 & $(0.736)$ & & & & \\
BEN & 0.859 & 0.568 & 0.396 & $0.494^{*}$ & $(0.753)$ & & & \\
TRANS & 0.822 & 0.615 & 0.396 & $0.436^{*}$ & $0.429^{*}$ & $(0.784)$ & & \\
OBSE & 0.793 & 0.538 & 0.224 & $0.371^{*}$ & $0.275^{\star}$ & $0.159^{*}$ & $(0.734)$ & \\
SE & 0.809 & 0.581 & 0.224 & $0.255^{*}$ & $0.198^{*}$ & $0.129^{*}$ & $0.273^{*}$ & $(0.762)$
\end{tabular}

$\mathrm{CR}=$ Composite Reliability, $\mathrm{AVE}=$ Average variance extracted $\mathrm{MSV}=$ maximum shared squared variance ${ }^{*}: p<0.05$. The number in parentheses denotes the square root of AVE.

Source: authors

Master validity tool developed by Gaskin and Lim (2016) was used to check the validity of the studied constructs. The validity of the constructs in the current study was evaluated based on calculation and comparison of average variance extracted (AVE), maximum shared squared variance (MSV) and Composite Reliability (CR). The figures in Table 1 indicate that the AVE value for any construct was greater than the MSV of that construct, confirming discriminant validity. Furthermore, all AVE values were found to be greater than 0.50 and lower than the respective Composite Reliability $(\mathrm{CR})$ value, showing no convergent validity issues.

Because data were collected from a single source, they are prone to Common Method Bias. Harman's single factor test was performed with all items in the dataset entered in an exploratory factor analysis which was forced to generate a single factor to evaluate the severity of this phenomenon. The resulting factor ultimately accounts for less than one-third 
$(31.36 \%)$ of the total variance. As a result, there were not severe problems with common method bias in this research.

\subsection{Non-response bias check}

Non-response bias has been checked using the approach of comparing early and late respondents on survey variables as suggested by Rogelberg and Stanton (2007). Mean differences tests were conducted on all multiple-item scales, assuming that late respondents represent non-respondents. Non-significant differences $(p>0.05)$ were obtained for all scales suggesting the absence of serious non-response bias in this study.

\subsection{Hypothesis testing}

\section{Figure 2 | SEM results}

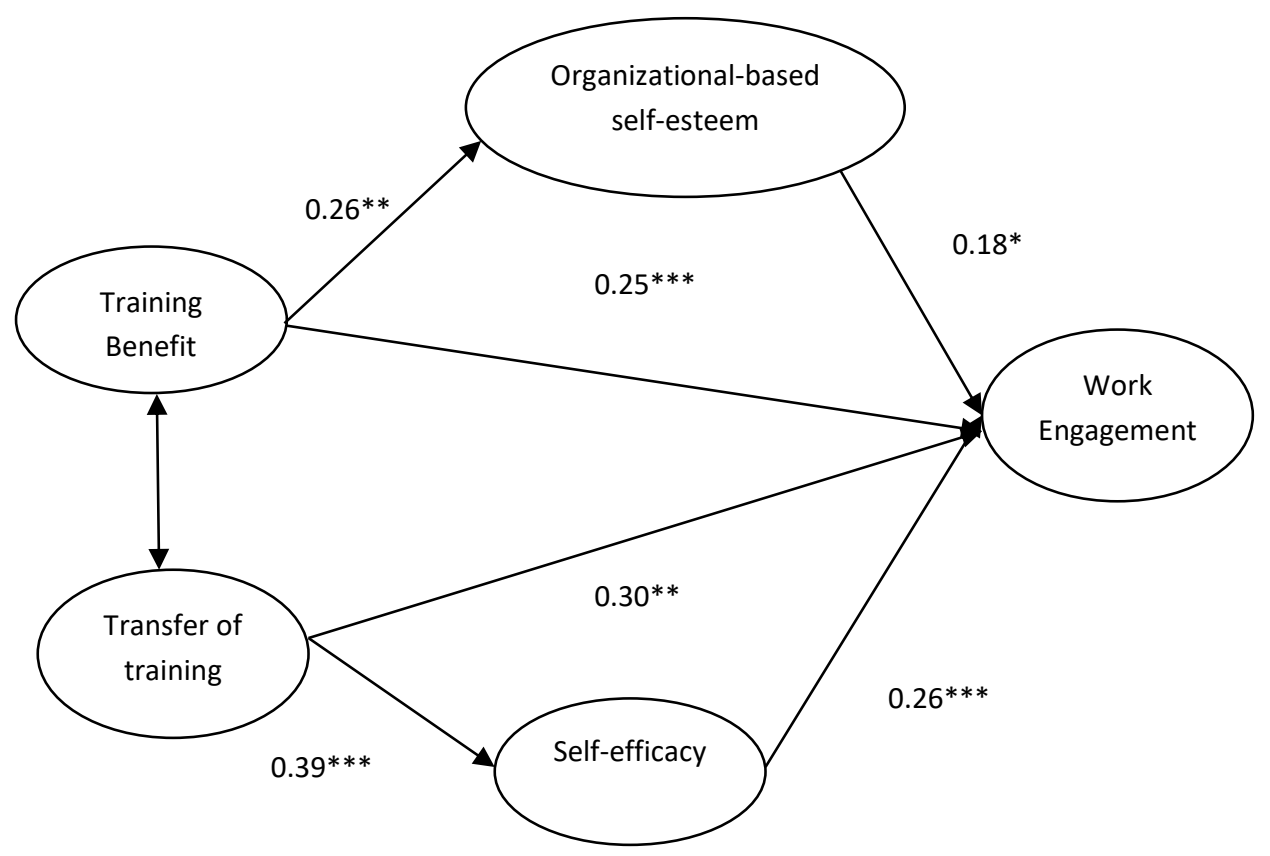

Note: $\mathrm{N}=364 ;{ }^{*}: \mathrm{p}<0.05 ;{ }^{* *}: \mathrm{p}<0.01 ;{ }^{* *}: \mathrm{p}<0.001$

Source: authors

AMOS software version 22.0 was adopted to test the hypotheses using the Structural Equation Modeling technique (SEM). The proposed model showed a good fit with the data $(\mathrm{Cmin}=569$, d.f. $=370, \mathrm{GFI}=0.90, \mathrm{CFI}=0.925 ; \mathrm{TLI}=0.916, \mathrm{RMSEA}=0.042, \mathrm{SRMR}=$ 0.065).

As depicted in Figure 2, BEN $(\beta=0.254, p<0.001)$ and TRANS $(\beta=0.30, p<0.01)$ had a positive and significant relationship with work engagement (WE). The data thus provide supports for Hypothesis $\mathrm{H} 1$ and $\mathrm{H} 2$.

The four predictors (BEN, TRANS, SE and OBSE) explain 48.6 per cent of the variance of WE. The impacts of BEN on OBSE $(\beta=0.26 p<0.01)$ and of OBSE on WE $(\beta=0.18, p<$ 
$0.05)$ are all positive and significant. In addition, the indirect effect of BEN on WE through OBSE $(\beta=0.046, p<0.01)$ is positive and significant, suggesting a partial mediation impact. Therefore, $\mathrm{H} 3$ is supported.

Similarly, the impacts of TRANS on SE $(\beta=0.39, p<0.001)$ and of SE on WE $(\beta=0.26, p<$ 0.01 ) are all positive and significant. In addition, the indirect effect of TRANS on WE through SE $(\beta=0.101, p<0.01)$ is positive and significant, also suggesting a partial mediation impact. Therefore, $\mathrm{H} 4$ is supported.

\section{Discussion and implications}

In the current research, perceived training benefits significantly and positively influence work engagement. In other words, trainees who perceive the association between training and intrinsic as well as extrinsic rewards will tend to engage deeply in work. This finding is generally in line with Fletcher et al. (2018), who proposed that perceived training opportunities influence work engagement. They posited that perceived benefits of training lead to the perception of intrinsic psychological needs satisfaction, such as meaningfulness, safety and availability, which in turn motivates the workers to engage more in their work. Dysvik and Kuvaas (2008) also found that perceived training opportunities, measured by training satisfaction, perceived training adequacy and subjective comparison of organisation's investments in training, was positively associated with role-work outcomes and OCB. Moreover, intrinsic motivation was confirmed as the mediator of the above relationships. Němečková (2012) studied the role of education and training as a source of workers' motivation in the context of the Czech Republic. The author indicated that regardless of individual characteristics, training and education significantly increase the employees' work motivation and commitment. Němečková (2012) also found that professional growth acted as an important mechanism through which training and education influence motivation. Šikýr (2013) surveyed executives and HR managers in the Czech Republic top 100 companies and found that regular and systematic training, with the aims to equip the employees with knowledge and skills for both current and future positions, is an important practice adopted by these successful companies. While previous research investigates the influence of perceived training opportunities, this research focuses on the impact of expected outcomes of training on work engagement. Therefore, besides having an opportunity to attend training, participants who perceived that training is beneficial and linked to positive rewards would be more engaged in the work. Susomrith and Coetzer (2019) found that learning through interactions with supervisors and colleagues were positively related to employees' work engagement. Thus it can be concluded that participation in training is less important than learning obtained from such training in determining work engagement.

The current study explores the influence of transfer of training on employee's work engagement. Results indicate that perceived training transferability causes positive and significant influences on employees' work engagement. It can be argued that the application of knowledge, skills and attitudes obtained from training into daily work can facilitate employees to perform the assigned task efficiently and accurately, create a positive willingness to provide high-quality job performance and focus on creative ways to fulfil the job. These positive impacts are related to vigour, dedication, and absorption, which are the dimensions of work engagement. The findings are in line with those reported by Nik Nazli and Sheikh Khairudin (2018), who found a positive relationship between the transfer of training 
and organisational citizenship behaviour. Similarly, Zumrah et al. (2013) reported that transfer of training significantly increased employee's service quality and job satisfaction. The authors proposed that the transfer of training contributes to the positive returns on training investment by improving the performance and work attitude of the participants. In a similar manner, Němečková (2012) proposed that companies in the Czech Republic should focus on specific training for particular employees and positions rather than conduct general mass training to improve the transfer of training. In another study of best practices in human resources among the top 100 companies in the Czech Republic, Šikýr (2013) also advised that employees training must be permanent and systematic. In addition, trainees should have the opportunities to apply their learning in work or as trainers or mentors. The findings of the current research add evidence to enhance our understanding of the consequences of the transfer of training. Although the transfer of training is one important issue in the human resource management field, the literature suggests that empirical research addressing its consequences for the individual worker are still limited (Zumrah et al., 2013), while previous studies mainly focused on the factors that influence the transfer of training in the workplace (Blume et al., 2010). In the same vein, Nik Nazli and Sheikh Khairudin (2018) also indicate that there is a lack of empirical research on the effect of transfer of training on employee performance and calls for more research effort.

Organisation-based self-esteem partially mediates the impact of perceived training benefits on work engagement. Participants who perceived the benefit of training activities tend to believe that they are important, meaningful, effectual and worthwhile within their organisation. Katono (2010) studied the influence of perceived training benefits on employee's attitudes. The author compared the trained and non-trained groups and found that the trained group perceived a higher level of support from their organisation than the non-trained group. Moreover, the untrained group perceived little peer support than the trained group. Thus it can be concluded that employees who participate in training seem to perceived OBSE than the other non trained employees. Fletcher et al. (2018) also advocated that perceptions of training may be interpreted by the employees as psychological contract fulfilment from the organisation's side, leading to the satisfaction of both intrinsic and extrinsic needs. A high level of OBSE would, in turn, lead to a higher level of work engagement (Bakker \& Demerouti, 2008; Costantini et al., 2019).

Extant literature has verified self-efficacy as a determinant of transfer of training (Blume et al., 2010; Burke \& Hutchins, 2007; lqbal \& Dastgeer, 2017). The current research confirmed the role of self-efficacy as a mediator of the causal relationship between the transfer of training and work engagement. In other words, the results suggest that successful transfer of training may exert a positive influence on self-efficacy in addition to the reverse causal relationship. Zumrah et al. (2013) argue that the application of learned skills and knowledge could offer fresh views on the job and improve and expand the employees' existing competencies. These, in turn, increase self-efficacy among employees. The positive link between self-efficacy and work engagement has been reported in previous studies (Consiglio et al., 2016; Chan et al., 2017). In line with this research's findings, self-efficacy has also been found as a mediator of the relationship between organisational such as transformational leadership (Prochazka et al., 2017) and job-related variables such as job challenge (Rai et al., 2020) and work engagement. 


\section{Conclusions and limitations}

This study provides empirical evidence to support interests in understanding the influence of training and development activities on work engagement. Our results suggest that in order for training interventions to foster work engagement, training should be linked with the participant's benefit and transferable to the daily work activities. In addition, a positive perception of training boosts employee's OBSE and self-efficacy, which in turn mediates the effect of training interventions on work engagement.

Besides the contributions, the current study also has some limitations. First, results are obtained from a cross-sectional research design. As the relationships among the variables could not be assessed in the long run, it remains unclear about the direction of the causal relationships among variables such as self-efficacy and transfer of training. Second, information used in the research was based on self-report responses and from a single data source. Although there has been no severe effect of common method bias in the current paper, it would be desirable to collect data from multiple sources such as management, peers, and subordinates in order to yield more robust results. Lastly, quantitative research was utilised as the sole method in this study. Adoption of other research methods might be helpful in explaining the relationships among variables.

Future studies may be conducted to address the identified weaknesses. The use of longitudinal research data, collection of multisource information, and a combination of qualitative or mixed methods can be fruitful in this topic. In addition, forthcoming research can expand the scope of the current paper in several areas. First, training is not likely to be provided in isolation; employees' perception regarding the overall management practices should be a solid predictor of work engagement. Second, other mechanisms and processes through which training affects employee's work engagement should be explored, such as trust in management or relational psychological contract. Third, the moderating effects of individual differences such as personality and career orientations could provide avenues for subsequent works.

\section{Acknowledgement}

This research is funded by Vietnam National Foundation for Science and Technology Development (NAFOSTED) under grant number 502.02-2020.06.

\section{References}

Aguinis, H., \& Kraiger, K. (2009). Benefits of training and development for individuals and teams, organisations, and society. Annual Review of Psychology, 60, 451-474. https://doi.org/10.1146/annurev.psych.60.110707.163505.

Ahmad, K. Z., \& Bakar, R. A. (2003). The association between training and organisational commitment among white-collar workers in Malaysia. International Journal of Training and Development, 7(3), 166185. https://doi.org/10.1111/1468-2419.00179.

Ahmad, I., \& Begum, K. (2020). Impact of abusive supervision on intention to leave: a moderated mediation model of organisational-based self esteem and emotional exhaustion. Asian Business Management. https://doi.org/10.1057/s41291-020-00116-0.

Alshahrani, H., \& Rasmussen Pennington, D. (2018). "Why not use it more?" Sources of self-efficacy in researchers' use of social media for knowledge sharing. Journal of Documentation, 74(6), 1274-1292. https://doi.org/10.1108/JD-04-2018-0051. 
Anitha, J. (2014). Determinants of employee engagement and their impact on employee performance. International Journal of Productivity and Performance Management, 63(3), 308-323. https://doi.org/10.1108/lJPPM-01-2013-0008.

Armstrong, M. (2000). Understanding training. Human Resource Management Practice. 8th Edition. Kogan page limited, London.

Arrowsmith, J., \& Parker, J. (2013). The meaning of 'employee engagement' for the values and roles of the HRM function. The International Journal of Human Resource Management, 24(14), 2692-2712. https://doi.org/10.1080/09585192.2013.763842.

Bailey, C., Madden, A., Alfes, K., \& Fletcher, L. (2017). The Meaning, Antecedents and Outcomes of Employee Engagement: A Narrative Synthesis. International Journal of Management Reviews, 19(1), 31-53. https://doi.org/10.1111/ijmr.12077.

Bakker, A. B., \& Demerouti, E. (2008). Towards a model of work engagement. The Career Development International, 13(3), 209-223. https://doi.org/10.1108/13620430810870476.

Bakker, A. B., Demerouti, E., \& Sanz-Vergel, A. I. (2014). Burnout and work engagement: The JD-R approach. Annual Review of Organizational Psychology and Organizational Behavior, 1, 389-411. https://doi.org/10.1146/annurev-orgpsych-031413-091235.

Bakker, A. B., Demerouti, E., \& ten Brummelhuis, L. L. (2012). Work engagement, performance, and active learning: The role of conscientiousness. Journal of Vocational Behavior, 80(2), 555-564. https://doi.org/10.1016/j.jvb.2011.08.008.

Bal, P. M., De Lange, A. H., Jansen, P. G. W., \& Van Der Velde, M. E. G. (2008). Psychological contract breach and job attitudes: A meta-analysis of age as a moderator. Journal of Vocational Behavior, 72(1), 143-158. https://doi.org/10.1016/j.jvb.2007.10.005.

Baldwin, T. T., \& Ford, J. K. (1988). Transfer of training: A review and directions for future research. Personnel Psychology, 41(1), 63-105. https://doi.org/10.1111/j.1744-6570.1988.tb00632.x.

Bandura, A. (1986). The explanatory and predictive scope of self-efficacy theory. Journal of Social and Clinical Psychology, 4(3), 359-373. https://doi.org/10.1521/jscp.1986.4.3.359.

Bandura, A. (1997). Self-efficacy: The exercise of control. W H Freeman/Times Books/ Henry Holt \& Co.

Bartlett, K. R. (2001). The relationship between training and organisational commitment: A study in the health care field. Human Resource Development Quarterly, 12(4), 335-352. https://doi.org/10.1002/hrdq.1001.

Bhatti, M. A., Battour, M. M., Sundram, V. P. K., \& Othman, A. A. (2013). Transfer of Training: Does it Truly Happen? An examination of support, instrumentality, retention and learner readiness on the transfer motivation and transfer of training. European Journal of Training and Development, 37(3), 273-297. https://doi.org/10.1108/03090591311312741.

Blau, P. M. (1964). Exchange and power in social life. New York: John Wiley.

Blume, B. D., Ford, J. K., Baldwin, T. T., \& Huang, J. L. (2010). Transfer of Training: A Meta-Analytic Review. Journal of Management, 36(4), 1065-1105. https://doi.org/10.1177/0149206309352880.

Bowling, N. A., Eschleman, K. J., Wang, Q., Kirkendall, C., \& Alarcon, G. (2010). A meta-analysis of the predictors and consequences of organisation-based self-esteem. Journal of Occupational and Organizational Psychology, 83(3), 601-626. https://doi.org/10.1348/096317909X454382.

Brunger, M., \& Spyra, K. (2018). Validation of the short-form Generalized Self-Efficacy scale (GSE-6) in rehabilitation. Revue d'Épidémiologie et de Santé Publique, 66(S5), 9-39. https://doi.org/10.1016/j.respe.2018.05.492. 
Burke, L. A., \& Hutchins, H. M. (2007). Training transfer: An integrative literature review. Human Resource Development Review, 6(3), 263-296. https://doi.org/10.1177/1534484307303035.

Carter, W. R., Nesbit, P. L., Badham, R. J., Parker, S. K., \& Sung, L. K. (2018). The effects of employee engagement and self-efficacy on job performance: a longitudinal field study. The International Journal of Human Resource Management, 29(17), 2483-2502. https://doi.org/10.1080/09585192.2016.1244096.

Chan, X. W., Kalliath, T., Brough, P., O'Driscoll, M., Siu, O.-L., \& Timms, C. (2017). Self-efficacy and work engagement: test of a chain model. International Journal of Manpower, 38(6), 819-834. https://doi.org/10.1108/lJM-11-2015-0189.

Chattopahyay, P., \& George, E. (2001). Examining the effects of work externalisation through the lens of social identity theory. Journal of Applied Psychology, 86(4), 781-788. https://doi.org/10.1037/00219010.86.4.781.

Chauhan, R., Ghosh, P., Rai, A., \& Kapoor, S. (2017). Improving Transfer of Training with Transfer Design: Does Supervisor Support Moderate The Relationship?. Journal of Workplace Learning, 29(4), 268-285. https://doi.org/10.1108/JWL-08-2016-0079.

Chin, W. W. (1998). Commentary: Issues and Opinion on Structural Equation Modeling. MIS Quarterly, 22(1), vii-xvi.

Consiglio, C., Borgogni, L., Di Tecco, C., \& Schaufeli, W. B. (2016). What makes employees engaged with their work? The role of self-efficacy and employee's perceptions of social context over time. The Career Development International, 21(2), 125-143. https://doi.org/10.1108/CDI-03-2015-0045.

Costantini, A., Ceschi, A., Viragos, A., De Paola, F., \& Sartori, R. (2019). The role of a new strengthbased intervention on organisation-based self-esteem and work engagement: $A$ three-wave intervention study. Journal of Workplace Learning, 31(3), 194-206. https://doi.org/10.1108/JWL-07-2018-0091.

Costen, W. M., \& Salazar, J. (2011). The Impact of Training and Development on Employee Job Satisfaction, Loyalty, and Intent to Stay in the Lodging Industry. Journal of Human Resources in Hospitality \& Tourism, 10 (3), 273-284. https://doi.org/10.1080/15332845.2011.555734.

Coyle-Shapiro, J., \& Kessler, I. (2000). Consequences Of The Psychological Contract For The Employment Relationship: A Large Scale Survey*. Journal of Management Studies, 37(7), 903-930. https://doi.org/10.1111/1467-6486.00210.

Demerouti, E., Bakker, A. B., Nachreiner, F., \& Schaufeli, W. B. (2001). The job demands-resources model of burnout. Journal of Applied Psychology, 86(3), 499-512. https://doi.org/10.1037/00219010.86.3.499.

Dhir, S., \& Shukla, A. (2019). Role of organisational image in employee engagement and performance. Benchmarking: An International Journal, 26(3), 971-989. https://doi.org/10.1108/BIJ-04-2018-0094.

Dysvik, A., \& Kuvaas, B. (2008). The relationship between perceived training opportunities, work motivation and employee outcomes. International Journal of Training and Development, 12(3), 138-157. https://doi.org/10.1111/j.1468-2419.2008.00301.x.

Fletcher, L. (2016). Training perceptions, engagement, and performance: comparing work engagement and personal role engagement. Human Resource Development International 19(1), 4-26. https://doi.org/10.1080/13678868.2015.1067855.

Fletcher, L., Alfes, K., \& Robinson, D. (2018). The relationship between perceived training and development and employee retention: the mediating role of work attitudes. The International Journal of Human Resource Management, 29(18), 2701-2728. https://doi.org/10.1080/09585192.2016.1262888. 
Frayne, C. A., \& Geringer, J. M. (2000). Self-management training for improving job performance: A field experiment involving salespeople. Journal of Applied Psychology, 85(3), 361-372. https://doi.org/10.1037/0021-9010.85.3.361

Gallup. (2017). State of the Global Workplace - Gallup Report (2017). Retrieved from: https://www.gallup.com/workplace/238079/state-global-workplace-2017.aspx.

Gardner, D. G., \& Pierce, J. L. (2016). Organisation-based self-esteem in work teams. Group Processes \& Intergroup Relations, 19(3), 394-408. https://doi.org/10.1177/1368430215590491.

Gaskin, J., \& Lim, J. (2016). Master validity tool. AMOS Plugin In: Gaskination's StatWiki.

Gordon, J. R., \& Hood, E. (2020). Organisation-based self-esteem and work-life outcomes. Personnel Review, 50(1), 21-46. https://doi.org/10.1108/PR-09-2019-0484.

Guan, X., \& Frenkel, S. (2019). How perceptions of training impact employee performance: Evidence from two Chinese manufacturing firms. Personnel Review, 48(1), 163-183. https://doi.org/10.1108/PR05-2017-0141.

Guest, D. (2002). Human Resource Management, Corporate Performance and Employee Wellbeing: Building the Worker into HRM. Journal of Industrial Relations, 44(3), 335-358. https://doi.org/10.1111/1472-9296.00053.

Haar, J. M., \& Brougham, D. (2016). Organisational-based self-esteem: A within country comparison of outcomes between Māori and New Zealand Europeans. Journal of Management \& Organization, 22(5), 720-735. https://doi.org/10.1017/jmo.2015.59.

Haddad, S., \& Taleb, R. A. (2016). The impact of self-efficacy on performance (An empirical study on business faculty members in Jordanian universities). Computers in Human Behavior, 55, 877887.https://doi.org/10.1016/j.chb.2015.10.032.

Hahn, H., \& Mathews, M. (2018). Learning behaviors as a linkage between organisation-based selfesteem and in-role performance. Journal of Management \& Organization, 1-16. https://doi.org/10.1017/jmo.2018.17.

Hallberg, U. E., \& Schaufeli, W. B. (2006). "Same Same" But Different? Can Work Engagement Be Discriminated from Job Involvement and Organisational Commitment? European Psychologist, 11(2), 119-127. https://doi.org/10.1027/1016-9040.11.2.119.

Hui, C., \& Lee, C. (2000). Moderating Effects of Organisation-Based Self-Esteem on Organisational Uncertainty: Employee Response Relationships. Journal of Management, 26(2), 215-232. https://doi.org/10.1177/014920630002600203.

Iqbal, K., \& Dastgeer, G. (2017). Impact of self-efficacy and retention on transfer of training: The mediating role of motivation to transfer. Journal of Management Development, 36(10), 1270-1282. https://doi.org/10.1108/JMD-06-2015-0087.

Kaakeh, A., Hassan, M. K., Van-Hemmen, S., \& Hossain, I. (2020). Understanding self-efficacy and performance of salespersons in Islamic banking. Journal of Islamic Accounting and Business Research, 11(5), 973-988. https://doi.org/10.1108/JIABR-10-2018-0160.

Kahn, W. A. (1990). Psychological conditions of personal engagement and disengagement at work. Academy of Management Journal, 33(4), 692-724. https://doi.org/10.2307/256287.

Katono, I. W. (2010). The role of perceived benefits of training in generating affective commitment and high value of firms. Strategic Change, 19(3-4), 141-146. https://doi.org/10.1002/jsc.864.

Kim, M., \& Beehr, T. A. (2018). Organisation-Based Self-Esteem and Meaningful Work Mediate Effects of Empowering Leadership on Employee Behaviors and Well-Being. Journal of Leadership \& Organizational Studies, 25(4), 385-398. https://doi.org/10.1177/1548051818762337. 
Knight, C., Patterson, M., Dawson, J., \& Brown, J. (2017). Building and sustaining work engagement - a participatory action intervention to increase work engagement in nursing staff. European Journal of Work and Organizational Psychology, 26(5), 634-649. https://doi.org/10.1080/1359432X.2017.1336999.

Kuvaas, B., \& Dysvik, A. (2009). Perceived investment in employee development, intrinsic motivation and work performance. Human Resource Management Journal, 19(3), 217-236. https://doi.org/10.1111/j.1748-8583.2009.00103.x.

Landy, F. J. (1985). Psychology of Work Behavior. I.L. Dorsey Press, Homewood.

Ling Suan, C., \& Nasurdin, A. M. (2014). An empirical investigation into the influence of human resource management practices on work engagement: the case of customer-contact employees in Malaysia. International Journal of Culture, Tourism and Hospitality Research, 8(3), 345-360. https://doi.org/10.1108/IJCTHR-12-2013-0083.

Lorente, L., Salanova, M., Martinez, I. M., \& Vera, M. (2014). How personal resources predict work engagement and self-rated performance among construction workers: A social cognitive perspective. International Journal of Psychology, 49(3), 200-207. https://doi.org/10.1002/ijop.12049.

Luthans, F., Avey, J. B., Avolio, B. J., \& Peterson, S. J. (2010). The development and resulting performance impact of positive psychological capital. Human Resource Development Quarterly, 21(1), 41-67. https://doi.org/10.1002/hrdq.20034.

Mache, S., Vitzthum, K., Wanke, E., Groneberg, D. A., Klapp, B. F., \& Danzer, G. (2014). Exploring the impact of resilience, self-efficacy, optimism and organisational resources on work engagement. Work: Journal of Prevention, Assessment \& Rehabilitation, 47(4), 491-500.

Manojlovich, M. (2005). Promoting nurses' self-efficacy: a leadership strategy to improve practice. Journal of Nursing Administration, 35(5), 271-278. https://doi.org/10.1097/00005110-200505000-00011.

McEvoy, G. M., Cragun, J. R., \& Appleby, M. (1997). Using Outdoor Training to Develop and Accomplish Organizational Vision. Human Resource Planning, 20(3), 20-28.

Memon, M., Salleh, R., \& Baharom, M. (2016). The link between training satisfaction, work engagement and turnover intention. European Journal of Training and Development, Vol. 40(6), 407-429. https://doi.org/10.1108/EJTD-10-2015-0077.

Morrison, E. W., \& Robinson, S. L. (1997). When employees feel betrayed: A model of how psychological contract violation develops. The Academy of Management Review, 22(1), 226-256. https://doi.org/10.2307/259230.

Němečková, I. (2012). Education as an Employee Motivation and Retention Factor of Banks and Financial Companies Operating in the Czech Republic. Central European Business Review, 1(1), 33-37. https://doi.org/10.18267/j.cebr.6.

Nik Nazli, N. N. N., \& Sheikh Khairudin, S. M. H. (2018). The factors that influence transfer of training and its effect on organisational citizenship behaviour: Evidence from Malaysia civil defence force. Journal of Workplace Learning, 30(2), 121-146. https://doi.org/10.1108/JWL-09-2017-0080.

Nishii, L. H., Lepak, D. P., \& Schneider, B. (2008). Employee attributions of the "why" of HR practices: Their effects on employee attitudes and behaviors, and customer satisfaction. Personnel Psychology, 61(3), 503-545. https://doi.org/10.1111/j.1744-6570.2008.00121.x.

Niu, H. J. (2010). Investigating the effects of self-efficacy on foodservice industry employees' career commitment. International Journal of Hospitality Management, 29(4), 743-750. https://doi.org/10.1016/j.ijhm.2010.03.006, 
Pierce, J. L., \& Gardner, D. G. (2004). Self-Esteem Within the Work and Organisational Context: A Review of the Organisation-Based Self-Esteem Literature. Journal of Management, 30(5), 591-622. https://doi.org/10.1016/j.jm.2003.10.001.

Pierce, J. L., Gardner, D. G., Cummings, L. L., \& Dunham, R. B. (1989). Organisation-based self-esteem: Construct definition, measurement, and validation. Academy of Management Journal, 32(3), 622-648. https://doi.org/10.2307/256437.

Prochazka, J., Gilova, H., \& Vaculik, M. (2017). The Relationship Between Transformational Leadership and Engagement: Self-Efficacy as a Mediator. Journal of Leadership Studies, 11(1), 22-33. https://doi.org/10.1002/jls.21518.

Rai, A., Patyal, V. S., \& Maheshwari, S. (2020). The Mediating Role of Self-efficacy between Job Challenges and Work Engagement: Evidence from Indian Power Sector Employees. Journal of Public Affairs, e2494. https://doi.org/10.1002/pa.2494.

Rich, B. L., LePine, J. A., \& Crawford, E. R. (2010). Job engagement: Antecedents and effects on job performance. Academy of Management Journal, 53(3), 617-635. https://doi.org/10.5465/AMJ.2010.51468988.

Rogelberg, S. G., \& Stanton, J. M. (2007). Introduction understanding and dealing with organisational survey non-response. Organizational Research Methods, 10(2), 195-209. https://doi.org/10.1177/1094428106294693.

Romppel, M., Herrmann-Lingen, C., Wachter, R., Edelmann, F., Dungen, H. D., Pieske, B., \& Grande, G. (2013). A short form of the General Self-Efficacy Scale (GSE-6): Development, psychometric properties and validity in an intercultural non-clinical sample and a sample of patients at risk for heart failure. GMS Psycho-Social-Medicine, 10, 1-7. https://doi.org/10.3205/psm000091.

Rousseau, D. M. (1995). Psychological contracts in organisations: Understanding written and unwritten agreements. Sage Publications, Inc.

Sahinidis, A. G., \& Bouris, J. (2008). Employee Perceived Training Effectiveness Relationship to Employee Attitudes. Journal of European Industrial Training, 32(1), 63-76. https://doi.org/10.1108/03090590810846575.

Saks, A. M. (2006). Antecedents and consequences of employee engagement. Journal of Managerial Psychology, 21(7), 600-619. https://doi.org/10.1108/02683940610690169.

Saks, A. M. (2019). Antecedents and consequences of employee engagement revisited. Journal of Organizational Effectiveness: People and Performance, 6(1), 19-38. https://doi.org/10.1108/JOEPP-062018-0034.

Salanova, M., Agut, S., \& Peiró, J. M. (2005). Linking Organizational Resources and Work Engagement to Employee Performance and Customer Loyalty: The Mediation of Service Climate. Journal of Applied Psychology, 90(6), 1217-1227. http://dx.doi.org/10.1037/0021-9010.90.6.1217.

Salanova, M., Llorens, S., \& Schaufeli, W. B. (2011). Yes, I can, I feel, I just do it!'On gain cyclesand spirals of efficacy beliefs, affect and engagement. Applied Psychology: AnInternational Review, 60(2), 255-285. https://doi.org/10.1111/j.1464-0597.2010.00435.x.

Salanova, M., Lorente, L., Chambel, M. J., \& Martínez, I. M. (2011). Linking transformational leadership to nurses' extra-role performance: the mediating role of self-efficacy and work engagement. Journal of Advanced Nursing, 67(10), 2256-2266. https://doi.org/10.1111/j.1365-2648.2011.05652.x.

Santos, A., \& Stuart, M. (2003). Employee perceptions and their influence on training effectiveness. Human Resource Management Journal, 13(1), 27-45. https://doi.org/10.1111/j.17488583.2003.tb00082.x. 
Schaufeli, W. B., Bakker, A. B., \& Salanova, M. (2006). The Measurement of Work Engagement With a Short Questionnaire: A Cross-National Study. Educational and Psychological Measurement, 66(4), 701716. https://doi.org/10.1177/0013164405282471.

Schaufeli, W. B., Salanova, M., González-Romá, V., \& Bakker, A. B. (2002). The measurement of engagement and burnout: $A$ two sample confirmatory factor analytic approach. Journal of Happiness Studies: An Interdisciplinary Forum on Subjective Well-Being, 3(1), 71-92. https://doi.org/10.1023/A:1015630930326.

Schaufeli, W. B., Shimazu, A., Hakanen, J., Salanova, M., \& De Witte, H. (2019). An ultra-short measure for work engagement: The UWES-3 validation across five countries. European Journal of Psychological Assessment, 35(4), 577-591. https://doi.org/10.1027/1015-5759/a000430.

Schaufeli, W., \& Salanova, M. (2008). Enhancing work engagement through the management of human resources. In K. Naswall, J. Hellgren, \& M. Sverke (Eds.), The Individual in the Changing Working Life (pp. 380-402). Cambridge: Cambridge University Press. https://doi.org/10.1017/CBO9780511490064.018.

Schmidt, S. W. (2007). The relationship between satisfaction with workplace training and overall job satisfaction. Human Resource Development Quarterly, 18(4), 481-498. https://doi.org/10.1002/hrdq.1216.

Schwarzer, R., \& Jerusalem, M. (1995). Generalised Self-Efficacy scale. In J. Weinman, S. Wright, \& M. Johnston, Measures in health psychology: A user's portfolio. Causal and control beliefs (pp. 35-37). Windsor, UK: NFER-NELSON.

Sendawula, K., Kimuli, S. N., Bananuka, J., \& Muganga, G. N. (2018). Training, employee engagement and employee performance: Evidence from Uganda's health sector. Cogent Business \& Management, 5(1), DOI: 10.1080/23311975.2018.1470891

Šikýr̆, M. (2013). Best Practices in Human Resource Management: The Source of Excellent Performance and Sustained Competitiveness. Central European Business Review, 2(1), 43-48. doi: $10.18267 / j . c e b r .38$.

Skarlicki, D. P., \& Latham, G. P. (1997). Leadership training in organisational justice to increase citizenship behavior within a labor union: A replication. Personnel Psychology, 50(3), 617-633. https://doi.org/10.1111/j.1744-6570.1997.tb00707.x

Stajkovic, A. D., \& Luthans, F. (1998). Self-efficacy and work-related performance: A meta-analysis. Psychological Bulletin, 124(2), 240-261. https://doi.org/10.1037/0033-2909.124.2.240.

Susomrith, P., \& Coetzer, A. (2019). Effects of informal learning on work engagement. Personnel Review, 48(7), 1886-1902. https://doi.org/10.1108/PR-10-2018-0430.

Tai, W. (2006). Effects of training framing, general self-efficacy and training motivation on trainees' training effectiveness. Personnel Review, 35(1), 51-65. https://doi.org/10.1108/00483480610636786.

Tesluk, P. E., Farr, J. L., Mathieu, J. E., \& Vance, R. J. (1995). Generalisation of employee involvement training to the job setting: Individual and situational effects. Personnel Psychology, 48(3), 607-632. https://doi.org/10.1111/j.1744-6570.1995.tb01773.x.

Towers Watson. (2012). Global Workforce Study: Engagement at Risk: Driving Strong Performance in a Volatile Global Environment. Retrieved from: https://employeeengagement.com/wpcontent/uploads/2012/11/2012-Towers-Watson-Global-Workforce-Study.pdf

Tran, H. P. (2019). How authentic leadership promotes individual knowledge sharing: viewing from the lens of COR theory. Management and Marketing, 14(4), 386-401. https://doi.org/10.2478/mmcks-20190027. 
Truitt, D. L. (2011). The Effect of Training and Development on Employee Attitude as it Relates to Training and Work Proficiency. SAGE Open. https://doi.org/10.1177/2158244011433338.

Truss, C., Shantz, A., Soane, A., Alfes, K., \& Delbridge, R. (2013). Employee engagement, organisational performance and individual well-being: exploring the evidence, developing the theory. The International Journal of Human Resource Management, 24(14), 2657-2669. https://doi.org/10.1080/09585192.2013.798921.

Van Dyne, L., \& Pierce, J. L. (2004). Psychological ownership and feelings of possession: Three field studies predicting employee attitudes and organisational citizenship behavior. Journal of Organizational Behavior, 25(4), 439-459. https://doi.org/10.1002/job.249.

Wollard, K. K., \& Shuck, B. (2011). Antecedents to Employee Engagement: A Structured Review of the Literature. Advances in Developing Human Resources, 13(4), 429-446. https://doi.org/10.1177/1523422311431220.

Xanthopoulou, D., Bakker, A. B., Demerouti, E., \& Schaufeli, W. B. (2009). Work engagement and financial returns: A diary study on the role of job and personal resources. Journal of Occupational and Organizational Psychology, 82(1), 183-200. https://doi.org/10.1348/096317908X285633.

Xanthopoulou, D., Bakker, A. B., Demerouti, E., \& Schaufeli, W. B. (2007). The role of personal resources in the job demands-resources model. International Journal of Stress Management, 14(2), 121-141. http://dx.doi.org/10.1037/1072-5245.14.2.121.

Zhao, H., Wayne, S. J., Glibkowski, B. C., \& Bravo, J. (2007). The impact of psychological contract breach on work-related outcomes: a meta-analysis. Personnel Psychology, 60(3), 647-680. https://doi.org/10.1111/j.1744-6570.2007.00087.x.

Zumrah, A. R., Boyle, S., \& Fein, E. C. (2013). The consequences of transfer of training for service quality and job satisfaction: An empirical study in the Malaysian public sector. International Journal of Training and Development, 17(4), 279-294. https://doi.org/10.1111/ijtd.12017.

The research paper passed the review process. | Received: March 6, 2021; Revised: May 31, 2021; Accepted: June 8, 2021; Pre-published: September 7, 2021; Published in the regular issue: May 19, 2022. 